\title{
A Soft Structure of Not-for-Profit Organization
}

\author{
Sarawut Sujitjorn*, Raweewan Lertsuksombat \\ Synchrotron Light Research Institute (Public Organization), Nakhon Ratchasima, Thailand \\ Email: *sarawut.sujitjorn@slri.or.th
}

How to cite this paper: Sujitjorn, S. and Lertsuksombat, R. (2019) A Soft Structure of Not-for-Profit Organization. Open Journal of Business and Management, 7, 1637-1640. https://doi.org/10.4236/ojbm.2019.74113

Received: July 31, 2019

Accepted: August 26, 2019

Published: August 29, 2019

Copyright (c) 2019 by author(s) and Scientific Research Publishing Inc. This work is licensed under the Creative Commons Attribution-NonCommercial International License (CC BY-NC 4.0). http://creativecommons.org/licenses/by-nc/4.0/

\begin{abstract}
This short communication proposes a soft structure of not-for-profit organizations (NPOs) usually owned by state governments. The proposed structure is a system representation of an organization. It represents operation, measure, administration, and safety. The proposed representation is flexible enough to be applied to many real NPOs as a tool for thought provoking, for instance during strategy forming phase.
\end{abstract}

\section{Keywords \\ Organizational Structure, Soft Structure}

\section{Introduction}

It is common for managers and CEOs to guide their management teams and employees to develop organizations' strategies. They bear in mind vision, mission, and organizational structure (or hard structure), and remind their colleagues such information. Sometimes they even show the connections between the hard structure, resources, and execution for strategic alignment. During strategy development phase, some tools are adopted as guidelines for strategic alignment. Balanced scorecard (BSC) [1], and Winning KPIs [2] for instance, have been widely used for the purpose. Thought provoking and connecting all the ideas to hard structure and management execution is not straightforward because the hard structure shows departmental composition of an organization not its management conceptual framework. During strategy forming and resource alignment, management conceptual framework is more relevant. Following the idea laid by Roberts Simon [3] for business enterprises, we proposed a layout of management conceptual framework, so called soft structure of an organization that is suitable for NPOs.

\section{Definition and Structure of NPOs}

NPOs are the type of enterprises that have no intentions or goals to gain profit 
from their businesses or missions. These include foundations, universities, research institutes, for instance. Such organizations aim to serve the society in various aspects, and give priority to impacts higher than monetary benefits. Such impacts include economic, societal, and environmental ones. Some may be owned by state governments; some may not, such as social enterprises, etc. The NPOs' general role is to serve society in various aspects for the good. For a state owned NPO, adequate resources are provided for by the government so that the organization performs to improve and enhance the community. Hence, the political role of an NPO is prominent. As such, the government transfers its responsibility in some areas to NPOs to deliver services to the society. Our proposed soft structure is illustrated in Figure 1. It represents interconnected phases of operation, control, and assessment referred to as three interconnected wheels. Notice that outcome wheel represents operation cycle of the NPO, which is culture or climate driven, i.e. strategic achievements rely on the driving culture of the organization. The third is impact wheel representing an assessment or measurement of the organization in terms of impacts. Business uncertainties are handled by safety measure and risk management. With this representation, managers and CEOs can easily guide their managerial teams and employees to visualize operation, assessment, and administrative cycles as a continuum. Thought provoking should start with the outcome wheel on operational plane. Receiving operating expenses and investment from governmental budget and partly from incomes, the organization is able to render services and innovation. The outcomes are then assessed for return of investment, and economic impacts. The operation can be best attained via proper management of employees, clients, and finance, hence climate wheel. It is necessary that the organizational culture is properly designed, implemented, and reinforced. Owing to the BSC, learning and growth perspective covers corporate culture because culture helps connect

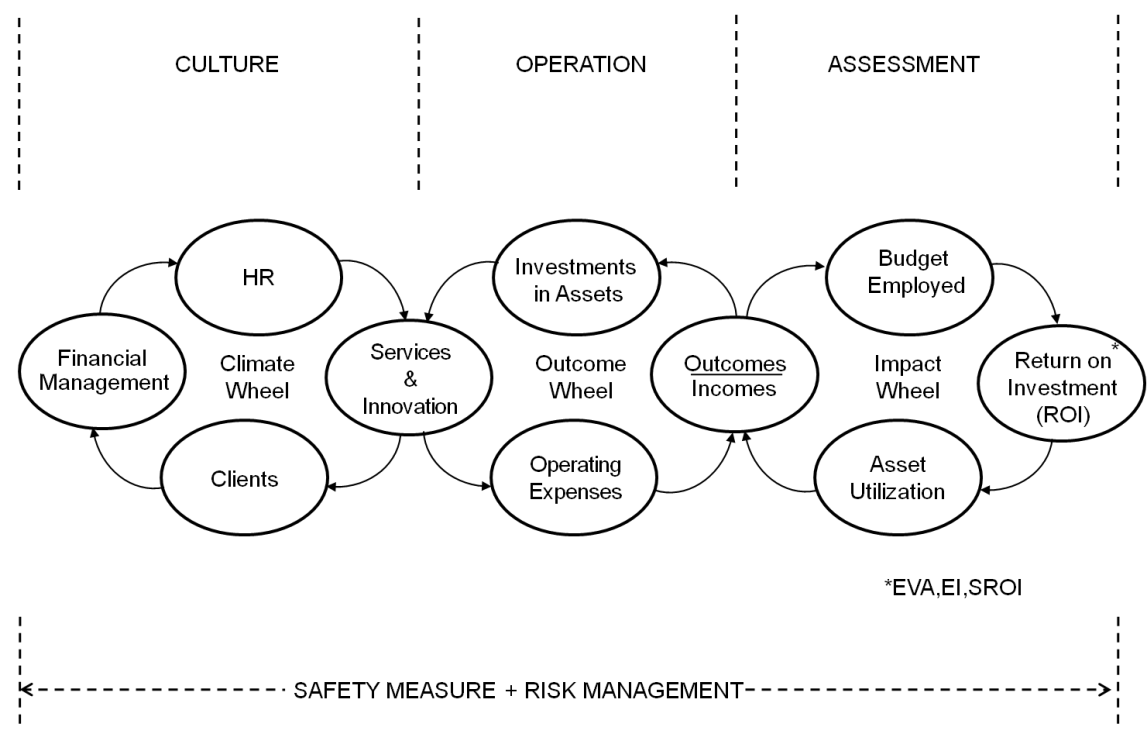

Figure 1. Soft structure or managerial conceptual framework of NPOs. 
and engage employees and customers. Each organization needs to carefully design its strategy [1] [4] [5], and tools are available [6]. Culture reinforcement is an important strategy for any organization, particularly an innovative one [7]. In the context, an organization must clearly understand its own missions, objectives, and purposes whether they are services with goals oriented, innovation or control and regulation. So, the organization can specify type(s) of culture correctly. Eventually, a successful implementation of strategy is a good management [8].

As a specific case, synchrotron light research institute (SLRI) is a not-for-profit organization owned by the Thai Government. Our missions that fit to the operation plane include research, development, and professional service provision. Our services cover synchrotron radiation for scientific research, analytic and research services, and engineering consultancy. By law, we can charge clients for service fees, however not our priority. The incomes return to be a part of our annual budget, though we are fully funded by the government. Our board of governance and the government are more interested in economic value added (EVA), environmental impact (EI), and social return of investment (SROI) that we could achieve each year. Therefore, effective marketing is vital for our success, and the institute has been run under culture-driven management style. In other words, our key driving force is from engaged employees to engaged customers. This kind of information is passed through from CEO to senior management team and employees to pursuit our aim to be a frontline NPO for scientific services and innovation. More details on SLRI can be found from http://www.slri.or.th.

This article is far from completion. It serves as a starting point for social scientists to design organizations, and executives to design strategy, culture, and safety measures for their organizations. The authors wish to urge our readers to provide feedback on applying the proposed structure to their specific contexts. Some possible applications may include designing a new organization, developing strategy, designing risk management program, designing employee engagement activities, and so forth.

\section{Conclusion}

The authors present their proposed organizational representation referred to as soft structure of not-for-profit organizations. The representation consists of three interconnected cycles, i.e. outcome, impact, and climate wheels. The organization operates its missions with a certain degree of safety and control (or safety measure and risk management). Performance can be best achieved via culture-driven management. In other words, the organizational culture should be properly designed, implemented, and reinforced.

\section{Acknowledgements}

The authors thank Tepparat Chittaku for her assistance on preparation of the 
figure.

\section{Conflicts of Interest}

The authors declare no conflicts of interest regarding the publication of this paper.

\section{References}

[1] Kaplan, R. and Norton, D. (1996) Translating Strategy into Action-The Balanced Scorecard. HBS Press, Boston. https://doi.org/10.1108/eb054566

[2] Parmenter, D. (2015) Key Performance Indicators-Developing, Implementing, and Using Winning KPIs. Wiley, Hoboken. https://doi.org/10.1002/9781119019855

[3] Simons, R.L. (1998) Templates for Project Planning. HBS Press, Boston.

[4] Porter, M.E. (1996) What Is Strategy? Harvard Business Review, 74, 61-78.

[5] Mintzberg, H., Ahlstrand, B. and Lampel, L. (1998) Strategy Safari. Free Press, New York.

[6] Evans, B. (2014) 25 Need-to-Know Strategy Tools. Pearson, London.

[7] Stein, E.W. (2014) Designing Creative High Power Teams and Organizations-Beyond Leaderships. Business Expert Press, New York.

[8] Mintzberg, H. (2013) Simply Managing. Berrett-Kochler, San Francisco. 